\title{
Developmental changes of peach-potato aphid (Myzus persicae Sulz.) under higher temperatures - the importance of a new phenomenon in the integrated protection of potato
}

\author{
Zmiany rozwojowe mszycy brzoskwiniowo-ziemniaczanej \\ (Myzus persicae Sulz.) w warunkach wyższych temperatur \\ - znaczenie nowego zjawiska w integrowanej ochronie ziemniaka
}

\author{
Maria Ruszkowska*, Przemysław Strażyński, Arleta Krówczyńska
}

\begin{abstract}
Summary
The temperature, photoperiod and nutritional quality of hostplants are the main factors affecting the emergence of sexual forms of aphids. Under certain conditions they can induce changes in the biology of aphids, which so far exhibited holocyclic development, for instance the peach-potato aphid (Myzus persicae Sulzer, 1776). Among the economically important species of aphids, this is particularly important, mainly as a vector of viruses in potatoes. In recent years the flights of this species have been registered in suction trap much longer than previously and the lack of males indicated that they may be mainly the anholocyclic forms. In parallel studies conducted in the environmental chambers, a cessation of the development of male and female egg-laying was detected as the effect of higher temperatures occurring under identified conditions of the photoperiod. As a result of this new phenomenon in the development of aphids an increase of their harmfulness is expected and not only in regards to viral diseases but also as a direct harmfulness, caused by new forms of development of this species. Knowledge of the phenomenon, combined with constant control of the plantation and monitoring mean daily temperatures are one of the basic elements of integrated protection of potato cultivation against M. persicae.
\end{abstract}

Key words: peach-potato aphid; Myzus persicae; development; temperature; photoperiod; quality of food; potato

\section{Streszczenie}

Temperatura, fotoperiod i jakość pokarmowa rośliny żywicielskiej to trzy podstawowe czynniki warunkujące powstawanie form płciowych mszyc. W określonych warunkach mogą one indukować zmiany w biologii mszyc, które do tej pory rozwijały się holocyklicznie, m.in. mszycy brzoskwiniowo-ziemniaczanej (Myzus persicae Sulzer, 1776). Spośród ważnych gospodarczo gatunków mszyc, ten ma szczególnie duże znaczenie, głównie jako wektor wirusów w ziemniaku. W ciągu ostatnich lat zarejestrowano aparatem ssącym Johnsona dłuższe okresy lotów oraz brak samców, co świadczyło, że mogą to być formy anholocykliczne. W prowadzonych równolegle badaniach w kabinach klimatycznych stwierdzono wstrzymanie rozwoju samców i samic jajorodnych na skutek działania wyższych temperatur w określonych warunkach długości fotoperiodu. Na skutek tego nowego zjawiska w rozwoju mszyc należy spodziewać się wzrostu ich szkodliwości, nie tylko w związku ze wzrostem zagrożenia chorobami wirusowymi, ale także szkodliwości bezpośredniej, wywołanej przez nowe formy rozwojowe tego gatunku. Znajomość zjawiska, w połączeniu ze stałą kontrolą plantacji oraz monitoringiem średnich dobowych temperatur stanowią jeden z podstawowych elementów integrowanej ochrony plantacji ziemniaka przed M. persicae.

Słowa kluczowe: mszyca brzoskwiniowo-ziemniaczana; Myzus persicae; rozwój; temperatura; fotoperiod; jakość pokarmowa; ziemniak

\footnotetext{
Instytut Ochrony Roślin - Państwowy Instytut Badawczy

Zakład Entomologii

Władysława Węgorka 20, 60-318 Poznań

*corresponding author: M.Ruszkowska@iorpib.poznan.pl
} 


\section{Wstęp / Introduction}

Aktywność enzymów mszyc umożliwia im silne i szybkie reakcje na wszelkie bodźce środowiskowe. Efektem tego jest błyskawiczne tempo adaptacji do nowych warunków bytowania. Temperatura, fotoperiod i jakość pokarmu są czynnikami warunkującymi powstawanie form płciowych wielu gatunków mszyc. Dla każdej wartości temperatury występuje inna wartość fotoperiodu, który skraca się wraz ze wzrostem temperatury. Krytyczna wartość długości dnia nie jest stała i zmniejsza się wraz ze wzrostem temperatury. Wysokie temperatury jesienią powodują opóźnienie w produkcji form płciowych. W temperaturze powyżej $25^{\circ} \mathrm{C}$ (z niewielkimi odchyleniami) stwierdzono, że u większości gatunków mszyc rozwijają się tylko dzieworódki (Kawada 1987; Ruszkowska 2004). Temperatura wywiera wpływ zarówno bezpośrednio na owada, jak i pośrednio przez roślinę żywicielską, decydując o szybkości procesów metabolicznych. Wrażliwość mszyc na temperaturę zależy od kilku czynników, m.in. gatunku mszycy i jego stadium rozwojowego, czasu działania temperatury, stopnia adaptacji termicznej, mrozoodporności rośliny żywicielskiej oraz składu chemicznego pokarmu. Wysokie temperatury, szczególnie w okresie suszy, powodują nadmierne parowanie wody z organizmu, co w konsekwencji może prowadzić do wyginięcia populacji (Hurej 1991). Występujące niskie temperatury wiosną hamują rozwój mszyc i aktywność migracyjną. Jednak po zasiedleniu upraw, w wyższej temperaturze, następuje gwałtowny wzrost reprodukcji (Leszczyński 1990). Z danych literaturowych wynika również, iż wysoka temperatura $\mathrm{w}$ połaczeniu $\mathrm{z}$ niskim poziomem, bądź całkowitym brakiem opadów, wyraźnie stymuluje wcześniejsze rozpoczęcie wiosennych migracji mszyc (Leszczyński i wsp. 2001).

Wszystkie gatunki holocykliczne charakteryzują się powstawaniem morf płciowych. Proces ten jest ściśle powiązany $\mathrm{z}$ odpowiednim układem długości dnia, temperatur i jakością pokarmową roślin żywicielskich. W strefie klimatu umiarkowanego większość gatunków tworzy formy płciowe jesienią, gdy stopniowo skraca się fotoperiod i spada temperatura (Lees 1959, 1963; Blackman 1975; Matsuka i Mittler 1979; Brodel i Schaeters 1980; Shaposhnikov 1987; Mittler i Wilhoit 1990; Harrington i wsp. 1995). Fotoperiodyzm odgrywa znaczącą rolę w rozwoju mszyc. Owady te rozwijające kilkanaście pokoleń w roku oraz mające wyraźnie zróżnicowany cykl życiowy, są szczególnie wrażliwe w odbiorze bodźców świetlnych (Szujecki 1980; Dixon 1998). Mszyce odbierają wrażenia świetlne poprzez wysoko wyspecjalizowany system nerwowo-czuciowy, za pośrednictwem komórek receptorów światła (Anderson i Bromley 1987). Natężenie światła, wpływając na komórki nerwowe, indukuje produkcję substancji hormonalnej, która z kolei może determinować płeć potomstwa w owariolach (Kawada 1987).

W warunkach środowiska naturalnego indukowanie zmian rozwojowych powstaje przede wszystkim na skutek działania wyższych temperatur. Temperatura $\geq 25^{\circ}$ wywołuje całkowitą permanentną partenogenezę nawet w warunkach krótkiego dnia, niezależnie od długości fotoperiodu (Kawada 1987). W szczególnych przypadkach rozwój obligatoryjnej partenogenezy mszyc wywoływany jest jakością pokarmową roślin żywicielskich - do uruchomienia tego procesu konieczny jest ciągły dostęp do młodych roślin (lub organów roślin) tego samego gatunku. Adler i wsp. (2007) badając wpływ długotrwałych zmian temperatur na poziom zagęszczenia mszyc na roślinie stwierdzili ponadto, że dalsze ocieplenie spowoduje zwiększoną interakcję między roślinożercą i rośliną, co może stymulować wtórne infekcje.

Spośród ważnych gospodarczo gatunków mszyc, mszyca brzoskwiniowo-ziemniaczana (Myzus persicae Sulzer, 1776) od dawna ma duże znaczenie, głównie jako wektor wirusów (van Emden i wsp. 1969; Mackauer i Way 1976; Eastop 1977). Jeszcze na początku XX wieku, jako m.in. jeden z najważniejszych szkodników ziemniaka, rozwijała się (także w Polsce) holocyklicznie, tzn. przechodziła pełen cykl rozwojowy zakończony zapłodnieniem (Judenko 1930, 1931). Impuls skracającego się dnia indukował powstawanie form płciowych w $100 \%$ populacji. Jako gatunek dwudomny, swój rozwój odbywała na dwóch żywicielach: pierwotnym (zimowym) - głównie brzoskwini, na którą migrowała jesienią i po zapłodnieniu składała jaja, oraz wtórnym (letnim) - m.in. na ziemniaku, na którym w zależności od warunków pogodowych rozwijała kilka do kilkunastu pokoleń - według Horsfall (1924) długość rozwoju $M$. persicae w tej samej temperaturze wynosi średnio 23 dni. W Polsce, w okresie powojennym notowano sporadyczne występowanie anholocyklicznych form M. persicae (Szelegiewicz 1968, 1978).

W ciągu ostatnich lat obserwuje się mszyce tego gatunku zasiedlające o wiele dłużej niż dotychczas rośliny ziemniaka - zjawisko to można tłumaczyć wcześniejszym wylęganiem się z jaj; w konsekwencji wcześniejszym przelotem na ziemniaki, opóźnionym rozwojem gynoparae oraz prawdopodobnie właśnie rozwojem anholocyklicznym. Zmiany te są efektem wystąpienia wyższych temperatur.

Celem przeprowadzonych badań było wykazanie dłuższego od dotychczasowego okresu występowania mszyc $M$. persicae na ziemniaku wraz z próbą wyjaśnienia tego zjawiska w warunkach naturalnych Wielkopolski. Praca ta nie przedstawia szczegółowych badań nad powstawaniem anholocyklii tego gatunku. Zmiany rozwojowe mszycy brzoskwiniowo-ziemniaczanej wyjaśnia się na podstawie analizy wyników wieloletnich odłowów aspiratorem Johnsona $\mathrm{w}$ korelacji $\mathrm{z}$ danymi temperaturowymi oraz obserwacjami rozwoju tych mszyc na roślinach w warunkach naturalnych i kontrolowanych w kabinach klimatycznych.

\section{Materiały i metody / Materials and methods}

W celu określenia progu temperaturowego i długości dnia, które indukują zmiany rozwojowe $M$. persicae prowadzono doświadczenia laboratoryjne w kabinie hodowlanej ze stałą temperaturą $25^{\circ} \mathrm{C}$ i stałym fotoperiodem (12 h dzień, $12 \mathrm{~h}$ noc). Mszyce pochodziły $\mathrm{z}$ upraw polowych ziemniaka, zbierano je w drugim tygodniu czerwca. Zebrane owady hodowano na młodych roślinach ziemniaka rosnących $\mathrm{W}$ donicach. W celu określenia i wyselekcjonowania form anholocyklicznych uskrzydlone 
formy mszyc odławiano za pomocą stojących w kabinie hodowlanej żółtych szalek. Po określonym czasie brak mszyc w żółtych szalkach świadczył o zahamowaniu procesu powstawania form holocyklicznych. Rozwijające się na ziemniaku mszyce nie odlatywały z zasiedlonych roślin, ponieważ ich cykl rozwojowy nie wymuszał na nich migracji na żywiciela pierwotnego.

$\mathrm{W}$ badaniach wykorzystano dane $\mathrm{z}$ wieloletnich odłowów mszyc aspiratorami Johnsona w Poznaniu i Winnej Górze (z lat 1971-2015) oraz dane meteorologiczne $z$ tego okresu - liczbę dni ze średnią temperaturą dobową w maju i czerwcu $\geq 25^{\circ} \mathrm{C}$ (Ruszkowska 2007). W identyfikacji mszyc wyodrębniono łącznie gynoparae i dzieworódki. Na ich osobne wyodrębnienie nie pozwalał brak różnic morfologicznych, natomiast samce występowały sporadycznie i to nie w każdym roku.

\section{Wyniki i dyskusja / Results and discussion}

Formy anholocykliczne $M$. persicae rozwinęły się na wykiełkowanych roślinach ziemniaka po około 2 tygodniach. W wyniku obserwacji określono progi temperaturowe wywołujące ciągłą partenogenezę (permanentne dzieworództwo) u M. persicae. Temperatura wywołująca te zmiany rozwojowe w $100 \%$ populacji wynosi $25^{\circ} \mathrm{C}$ przez co najmniej trzy dni w okresie do 21 czerwca (przed efektem skracającego się dnia). W warunkach naturalnych przyjęto, że średnia dobowa temperatura $\geq 25^{\circ} \mathrm{C}$ w maju i czerwcu wywołuje zmiany w pełnym cyklu rozwojowym tego gatunku mszycy. Tak wczesne zmiany rozwojowe mogą mieć konsekwencje w rozwoju chorób wirusowych na ziemniaku. Analizując wieloletnie dane meteorologiczne stwierdzono wzrost liczby takich dni, szczególnie W ostatnich 15 latach (rys. 1). Podane w literaturze wartości krytyczne długości dnia dla rozwoju anholocyklii M. persicae $(14,5 \mathrm{~h})$ nie sprawdzają się $\mathrm{w}$ przypadku wystąpienia temperatury wyższej od $25^{\circ} \mathrm{C}$. W naszych warunkach pogodowych długość dnia $14 \mathrm{~h}$, uznana za wartość progową rozwoju anholocyklii $M$. persicae, sprawdza się tylko w przypadku wystąpienia temperatur niższych od $25^{\circ} \mathrm{C}$. Wartości krytyczne rozwoju anholocyklii w warunkach naturalnych muszą być podawane łącznie z temperaturą. Należy również uwzględnić jakość pokarmową roślin żywicielskich (wiek rośliny). W polskich warunkach klimatycznych w okresie długości dnia 14,5 h nie występują tak wysokie temperatury.

Uwzględnia się średnią dobową temperaturę wyższą od $25^{\circ} \mathrm{C}$, ponieważ nie wiadomo, jak długo konieczna jest ekspozycja tej wartości. Należy również pamiętać, że w okresie krótkiego dnia starzejące się rośliny nie stymulują rozwoju anholocyklii. Jednakże wpływ wyższych temperatur może przejawiać się opóźnieniem wystąpienia gynoparae i uniemożliwić rozwój samców. Analiza danych dotyczących mszyc zarejestrowanych aspiratorem Johnsona w latach 1973-2011 wykazała znaczny spadek liczebności samców mszyc (Ruszkowska i Strażyński 2011). Być może formy anholocykliczne (należy przypuszczać, że na pewno), rozwijają się w ciągu całego okresu wegetacji, zwłaszcza w okresie, kiedy rośliny są jeszcze stosunkowo młode, w przypadku wystąpienia temperatur wyższych od $25^{\circ} \mathrm{C}$.

Stwierdzenie ciągłej partenogenezy $M$. persicae na ziemniaku jest wskaźnikiem wystąpienia wyższych od dotychczasowych temperatur w okresie maja i czerwca. Na skutek tego nowego zjawiska w rozwoju mszyc należy spodziewać się wzrostu ich szkodliwości. Wśród mszyc odłowionych aspiratorem Johnsona stwierdzono dłuższy od dotychczasowego (począwszy od 1971 roku) okres występowania $M$. persicae - co świadczyło, że mszyce te wcześniej zasiedlały rośliny i dłużej na nich żerowały (rys. 2, 3). Wcześniejsze wiosenne odłowy mszyc $M$. persicae aspiratorem Johnsona mogą świadczyć o przyspieszonym rozwoju dzięki wyższym temperaturom w styczniu i lutym (Spellerberg 2005), a także o możliwości przezimowania klonów anholocyklicznych z powodu nie wystąpienia temperatur krytycznych w rozwoju żyworodnych mszyc, tj. $-6^{\circ} \mathrm{C}$.

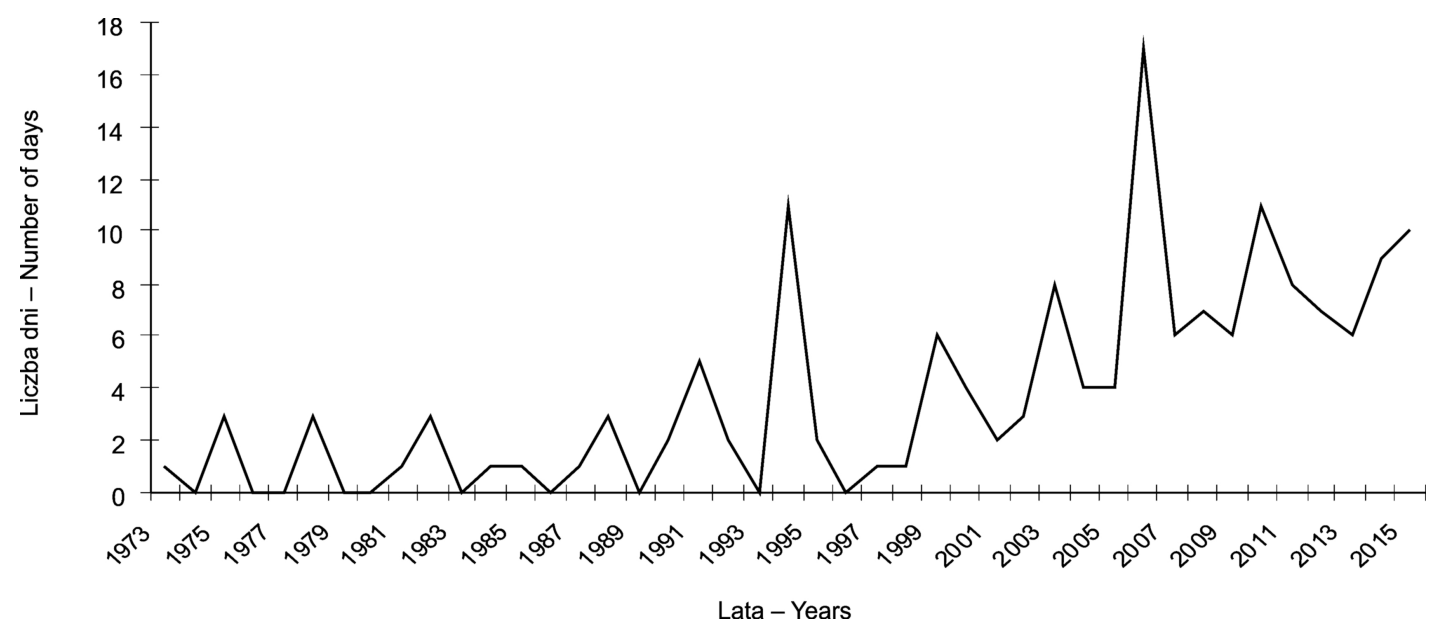

Rys. 1. Liczba dni w roku ze średnią temperaturą dobową $\geq 25^{\circ} \mathrm{C}$ w maju i czerwcu w latach 1973-2015

Fig. 1. The number of days within a year with an average daily temperature $\geq 25^{\circ} \mathrm{C}$ in May and June in the years $1973-2015$ 


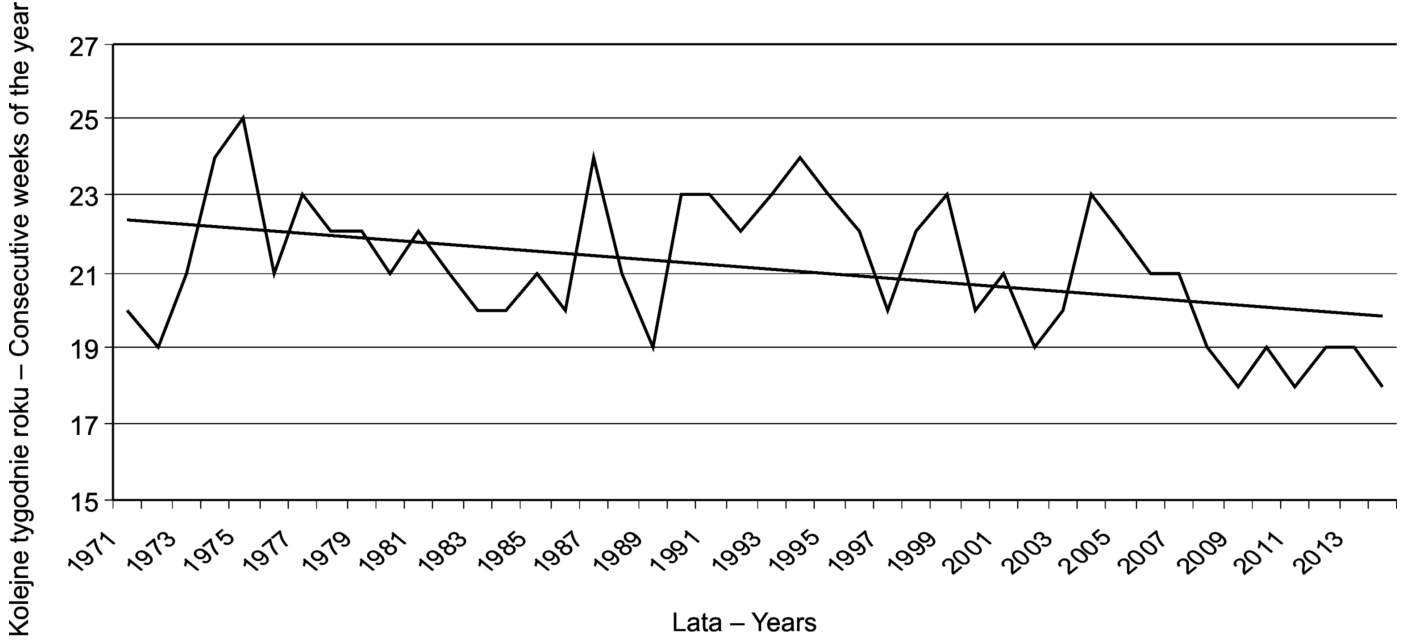

Rys. 2. Terminy pierwszych odłowów Myzus persicae aspiratorem Johnsona w kolejnych latach w Wielkopolsce

Fig. 2. Dates of the first catches of Myzus persicae by Johnson's suction trap in subsequent years in Wielkopolska

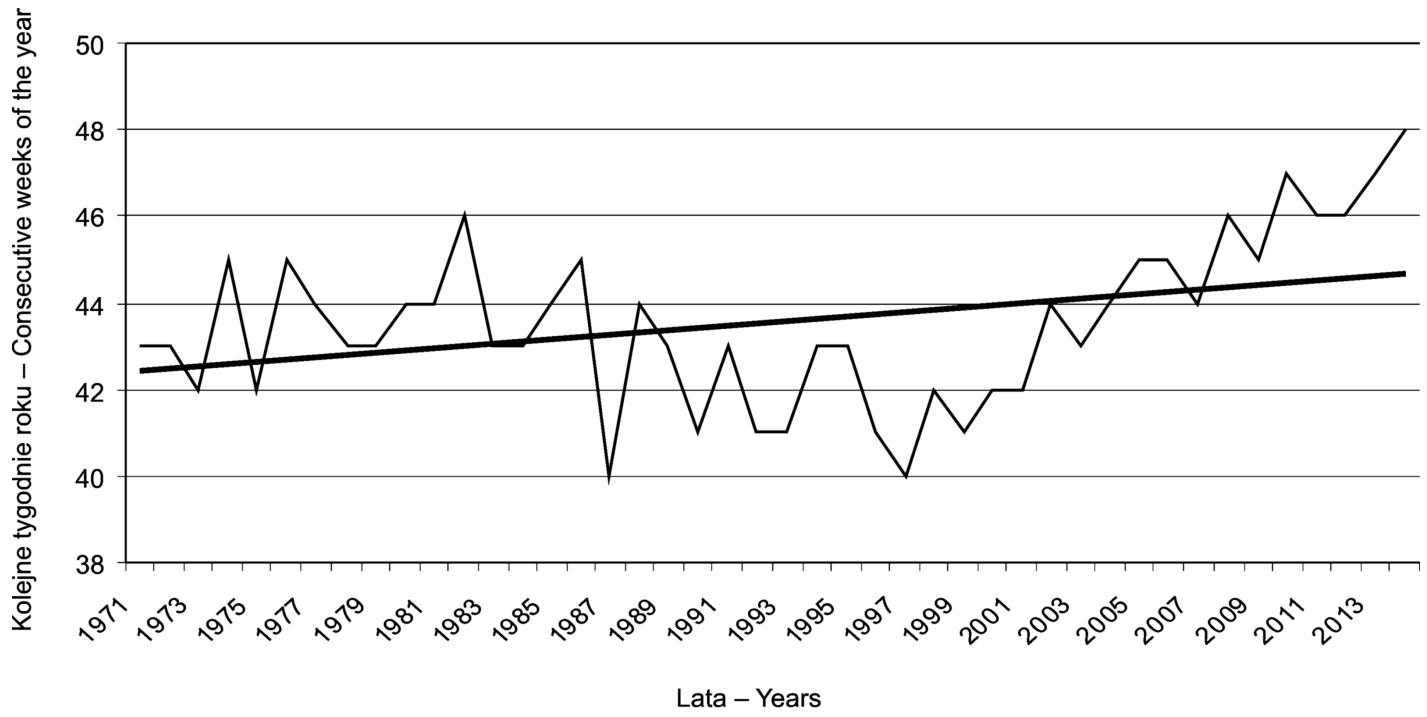

Rys. 3. Terminy ostatnich odłowów Myzus persicae aspiratorem Johnsona w kolejnych latach w Wielkopolsce

Fig. 3. Dates of the last catches of Myzus persicae by Johnson's suction trap in subsequent years in Wielkopolska

\section{Wnioski / Conclusions}

1. Wydłużenie okresu odłowów aspiratorem Johnsona mszyc $M$. persicae w połączeniu ze sporadycznym występowaniem samców w odłowach świadczy o wydłużonym rozwoju klonów holocyklicznych i również o pochodzeniu części populacji z klonów anholocyklicznych.

2. Obecnie należałoby się liczyć nie tylko ze wzrostem zagrożenia chorobami wirusowymi przenoszonymi przez $M$. persicae, ale także szkodliwości bezpośred- niej, wywołanej przez nowe formy rozwojowe tego gatunku; rośliny ziemniaka, zwłaszcza we wczesnych fazach rozwoju, masowo zasiedlone mszycami (głównie ich bezskrzydłymi morfami) mogą całkowicie zamierać.

3. Znajomość zjawiska, w połączeniu ze stałą kontrolą plantacji oraz monitoringiem średnich dobowych temperatur $\mathrm{w}$ okresie maja i czerwca stanowią jeden $\mathrm{z}$ podstawowych elementów integrowanej ochrony plantacji ziemniaka przed $M$. persicae.

\section{Literatura / References}

Adler L.S., de Valpine P., Harte J., Call J. 2007. Effect of long-term experimental warming on aphid density in the field. Journal of Kansas Entomological Society 89 (2): 156-168.

Anderson M., Bromley A.K. 1987. Sensory system. p. 153-161. In: "World Crop Pests. Aphids. Their Biology, Natural Enemies and Control” (A.K. Minks, P. Harrewijn, eds.). Elsevier, Vol. 2A, 450 pp. 
Blackman R.L. 1975. Photoperiodic determination of the male and female sexual morphs of Myzus persicae. Journal of Insect Physio$\log 21$ (2): 435-453.

Brodel C.F., Schaeters G.A. 1980. The influence of temperature on the production of sexuals by Aphis rubicola under short-day conditions. Entomologia Experimentalis et Applicata 37: 127-132.

Dixon A.F.G. 1998. Resource tracking: mechanism - cyclical parthenogenesis. p. 83-84. In: “Aphid Ecology” (A.F.G. Dixon, ed.). Publisher Chapman \& Hall, 300 pp.

Eastop V.F. 1977. Worldwide importance of aphids as virus vectors. p. 4-44. In: "Aphids as Virus Vectors" (K.F. Harris, K. Maramorosch, eds.). Academic Press, 647 pp.

Harrington R., Bale J.S., Tatchell G.M. 1995. Aphids in a changing climate. p. 126-150. In: "Insects in a Changing Environment" (R. Harrington, N.E. Stark, eds.). 17th Symposium of the Royal Entomological Society of London, 7-10 September 1993, Academic Press, $535 \mathrm{pp}$.

Horsfall 1924. Life history studies of Myzus persicae Sulzer. Pennsylvania Agricultural Experiment Station Bulletin 185,16 pp.

Hurej M. 1991. Wrażliwość mszyc na ekstremalne temperatury. Wiadomości Entomologiczne 1: 42-49.

Judenko E. 1930. Materjały do fauny mszyc (Aphididae) okolicy Puław z uwzględnieniem biologji. Lwów, Polskie Pismo Entomologiczne 9: 129-186.

Judenko E. 1931. Materjały do fauny mszyc (Aphididae) okolicy Puław z uwzględnieniem biologji. Lwów, Polskie Pismo Entomologiczne 10: 102-118.

Kawada K. 1987. Polymorphism and morph determination. p. 255-265. In: "World Crop Pests. Aphids. Their Biology, Natural Enemies and Control" (A.K. Minks, P. Harrewijn, eds.). Elsevier, Vol. 2A, 450 pp.

Lees A.D. 1959. The role of photoperiod and temperature in the determination of parthenogenetic and sexual forms in the aphid Megoura viciae Buckton. I. The influence of those factors on apterous virginoparae and their progeny. Journal of Insect Physiology 3: $92-117$.

Lees A.D. 1963. The role of photoperiod and temperature in the determination of parthenogenetic and sexual forms in the aphid Megoura viciae Buckton. III. Further properties of the material switching mechanism in apterous aphids. Journal of Insect Physiology 13: 289-318.

Leszczyński B. 1990. Wpływ czynników klimatycznych na populację mszyc zbożowych. Zeszyty Problemowe Postępów Nauk Rolniczych 392: 123-131.

Leszczyński B., Urbańska A., Wereda I. 2001. Some factors influencing spring and autumn migrations of bird cherry-oat aphid in Eastern Poland. p. 223-230. In: “Aphids and other Homopterous Insects”, Vol. 8, PAS, Siedlce, 439 pp.

Mackauer M., Way M.Y. 1976. Myzus persicae Sulz., an aphid of world importance. p. 51-119. (V.F. In Delucchi, ed.). Studies in Biological Control. Cambridge University Press.

Matsuka M., Mittler T.E. 1979. Production of males and gynoparae by apterous viviparae of Myzus persicae continously expose to different scotoperiods. Journal of Insect Physiology 25: 587-593.

Mittler T.E., Wilhoit L. 1990. Sexual morph production by two regional biotypes of Myzus persicae (Homoptera: Aphididae) in relation to photoperiod. Environmental Entomology 19: 111-126.

Ruszkowska M. 2004. Modyfikacja progów szkodliwości i metody alternatywne w warunkach powstawania nowych form rozwojowych mszyc. [Modification of pest thresholds and alternative methods in conditions of the development of new aphid forms]. Progress in Plant Protection/Postępy w Ochronie Roślin 44 (1): 347-354.

Ruszkowska M. 2007. Across the transformation life cycle of Rhopalosiphum padi (L.) (Homoptera: Aphidoidea): coevolution with temperature. Rozprawy Naukowe Instytutu Ochrony Roślin, Zeszyt 15, 60 ss.

Ruszkowska M., Strażyński P. 2011. Elementy zmian w bionomii mszyc dendrofilnych w środowisku zurbanizowanym. Zeszyty Problemowe Postępów Nauk Rolniczych 562: 221-227.

Shaposhnikov G.Ch. 1987. Organization (Structure) of population and species, and speciation. p. 415-428. In: "World Crop Pests. Aphids. Their Biology, Natural Enemies and Control" (A.K. Minks, P. Harrewijn, eds.). Elsevier, Vol. 2A, 450 pp.

Spellerberg J. 2005. Monitoring Ecological Change. 2nd ed. Cambridge Univ. Press. Information provided by Richard Harrington 39: $72-73$.

Szelegiewicz H. 1968. Mszyce - Aphidoidea. Katalog Fauny Polski. PWN, Warszawa, XXI (4), 316 ss.

Szelegiewicz H. 1978. Przemiany w faunie mszyc Polski w latach 1956-1976. Zeszyty Problemowe Postępów Nauk Rolniczych 208: $113-125$

Szujecki A. 1980. Ekologia owadów leśnych. PWN, Warszawa, 603 ss.

van Emden H.F., Eastop V.F., Hughes R.D., Way M.J. 1969. The ecology of Myzus persicae. Annual Review of Entomology 14: $197-270$. 